\title{
Community-Police Relations and Informant Identity Protection: Evidence from Some Selected Communities in the Brong-Ahafo Region, Ghana
}

\author{
Francess Dufie Azumah'1, Joana Obeng Nyarko², Samuel Krampah', John Onzaberigu Nachinaab ${ }^{1}$ \\ ${ }^{1}$ Department of Sociology and Social Work, Kwame Nkrumah University of Science and Technology, Kumasi, Ghana \\ ${ }^{2}$ Institute of Distance Learning, Kwame Nkrumah University of Science and Technology, Kumasi, Ghana \\ Email: fazumah@hotmail.com, obanyarko@yahoo.com, Skrampah002@yahoo.com, onachinaabjohn@gmail.com
}

How to cite this paper: Azumah, F. D., Nyarko, J. O., Krampah, S., \& Nachinaab, J. O. (2019). Community-Police Relations and Informant Identity Protection: Evidence from Some Selected Communities in the Brong-Ahafo Region, Ghana. Current Urban Studies, 7, 228-246.

https://doi.org/10.4236/cus.2019.72011

Received: June 5, 2019

Accepted: June 24, 2019

Published: June 27, 2019

Copyright $\odot 2019$ by author(s) and Scientific Research Publishing Inc. This work is licensed under the Creative Commons Attribution International License (CC BY 4.0).

http://creativecommons.org/licenses/by/4.0/

\begin{abstract}
For effective crime control, the roles of informants are critical. The police and community members' relation is needed for the police continuous reliance on informants' information on crime. This has been the principle for fighting crime in many parts of the developed countries in the World. The study sought to examine the relations between community and police in providing protection for informants in crime investigation within communities (Tepa and Hwediem) in Brong-Ahafo Region, placing much emphasis on the relationship between community members and police in providing information for combating crime, the effectiveness of informants' information in fighting crime and measures that could improve the relationship between community members and police in protecting informants. Social survey design was adopted. Cluster sampling and simple random were used to select 400 respondents (community members and police). Quantitative approach was adopted. The study found that informants were relatively fewer in the community. The study found that respondents who reported criminal cases to the police indicated that their act was very important in fighting crime. It was concluded that a good relationship between community members and police was needed to protect informants. The results showed that majority of the respondents strongly agreed informants' identities should not be revealed to suspects. The researchers recommended that since effective communication is fundamental to positive police-community relationships, the Government and Ghana Police Service (GPS) should seek to provide its officers with an understanding of language diversity. The researchers then again recommended that officers of the GPS should be provided with an in-service training by the Government and GPS to improve community policing and trust building.
\end{abstract}




\section{Keywords}

Police, Informant, Community, Crime

\section{Introduction}

The police have largely relied on community members in the fight against crime (Lum \& Nagin, 2017). For effective crime control, the roles of informants are critical. There are still concerns about effective police and community relationship in fighting against crime (Chatterton, 2009). The police and community members' relationship is needed for the police to continue relying on informants for information on crime (Bergstrom, 2015). This has been the principle for fighting crime in many parts of developed countries in the World. A study by Blackmore (2014) showed that American Criminal Justice System, not just relied on community members for information on criminal activities, but frequently used informants information in combating crime. The police and informants network sources have been seriously studied by researchers comprehensively. To have the capacity to give noteworthy data on crime, studies have demonstrated that much effort ought to be outfitted including informants in recognizing lawbreakers. As indicated by Donnelly (2011), a considerable measure of honest individuals gets indicted for crimes they do not submit because of the absence of data. This makes it essential for successful joint effort between the community members and police since that will give sources of expectation and trust in the police (Caldero \& Crank, 2010). Witnesses have throughout the years given solid data to the police on crimes conferred by the citizenry, yet they have not been legitimately ensured and compensated for their endeavors with regards to police and specialists rebuffing guilty parties (Schulhofer, 2013). The indictment of all, most and many pack, horde, debasement, extortion, fear mongering, and kill for-enlist cases which data are given by community members and solid witnesses have not met the longing of most sources which makes many people keep information about violations without imparting to the police (Clark \& Tiff, 2016).

In most African nations, police and security expert have perceived the need to depend on community members and sources of data to capture, explore, and indict culprits of crime (Weiss, 2016). The police and courts have determined utilization of sources of information from time immemorial in securing criminals. In instances of scheme, or in different situations when crimes occur in societies, it is typically important to depend on informants' information. As per Brown (2007), under present day police condemning practices in most African nations, such courses of action have turned out to be very formal and the police and security administrations have now observed the need and significance of witnesses in battle against crime and acquiring data with regards to criminal exercises. The 
capture of such culprits regularly starts with informants' information which must be acquired from compelling connection between the police and the community (Schreiber, 2001). The police and other security agencies have over the years use information from confidential informants in crime investigation. However, most informants with useful information about criminals find it difficult giving information to the police for many reasons known only to them (Wisotsky, 1986). Studies have demonstrated that it is a piece of the police standards to depend on information given by informants in battling and capturing criminals (Manning, 2004). Informants have throughout the years given valuable information to the police on criminal conduct. However, the police have taken it in their potential outcomes for progress by developing the propensity for looking for information from sources, since the vast majority of community people are not always ready to give information on criminal activities due to dread of terrorizing from culprits. From the prosecution point of view, informants are almost indispensable in narcotics and some criminals cases (Harney \& Cross, 2008).

Notwithstanding, in Ghana, individuals who have information that could help the police in arresting criminals and reducing crime have neglected to do so because of absence of assurance from the police to protect informants. Most informants have always cited that lack of protection of their privacy after they have reported or provided the police with information in aiding criminals arrest prevents them from cooperating with the police (Hartley, Maddan, \& Spohn, 2007). The problem about police-community relationship in fighting crime is that there is always lack of trust between the community members and the police. Most community members feel that the police do not effectively execute reported cases to their satisfaction and as a result of that most criminals are left to go free after an informant has provided useful information that could lead to the arrest and sentence of offenders. Informants extend the reach and perceived presence of law enforcement agency as not providing enough protection to them and that cases are not well carried out after reports from informants.

Informants also intensify enforcement operations through close association with criminal targets and entry into settings otherwise off-limits to undercover officers (Geberth, 2009). The legal restrictions placed on informant conduct are less defined than for sworn agents and the likelihood of formal disclosure of an informant's identity is small. Accountability checks beyond the immediate supervising agents for whom they work are unlikely as well, suggesting informants have considerable autonomy in maneuvering within undercover roles to achieve deeper penetration into criminal operations with less time, legal complexity, and accountability than detectives (Brown, 2007). However, one is tempted to ask of the roles the police play to ensure that there is a good relationship between them and the community members to obtain information from informants. How are informants' privacy protected in the Brong-Ahafo Region of Ghana? This study seeks to examine community members and police relationship by analyzing how 
informants' freedom and privacy are protected in fighting against crime.

\section{Objectives}

The general objective of the study was to examine the relationship between community members and police in providing protection and privacy for informants in crime investigation. Specifically, the study sought to:

1) To examine the relationship between the community members and the police in providing information for the police in fighting crime and how best to improve the relationship.

2) To determine the effectiveness of informants' information in fighting crime.

\section{Literature Review}

There is nothing new about police relying on informants to make cases. Nor is there anything new about prosecutors relying on cooperators to prove them (Adler \& Adler, 2008). Such informational transactions have come to be a hallmark of the Criminal Justice System, not just because they are so frequently used, but because these morally fraught arrangements are largely unregulated by formal law, pose a risk to investigative and adjudicative reliability, and yet hold a promise of bringing to justice those who exercise illegitimate power. Informants and cooperators have been presumed prominently in studies (Adkins, 2007).

The exchanging of tolerance for information likewise undermines the objectives of flat value in condemning and can leave dangerous criminals under-rebuffed, even ready to perpetrate violations with exemption. However, without these game plans, informants need to swear off the indictment of many groups, crowd, debasement, extortion, fear mongering, and kill for-enlist cases, and also trafficking cases, of all shapes and sizes, that so regularly figure in scrutinizes (Becker, 2013). Becker (2009) also might have to consider levels of undercover policing and surveillance that we have found intolerable or prohibitively expensive. Even a well-regulated system would be hard-pressed to ensure that these deals are done in the right cases for the right reasons, and that, when done, they are free from the dangers of self-dealing by police overeager to make cases, prosecutors looking to post convictions at any cost, informants seeking impunity, and cooperators currying favor at the expense of truth (Benson, 2015). The function of the informer is usually limited to revealing information to law enforcement authorities. Despite general public reluctance to become involved in police affairs and prevailing moral opposition to informing (street codes and "Stop Snitching" movements), the popularity of crime prevention programs (Silent Witness and Crime Stoppers) suggests that ongoing cooperation is fairly normative (Pfuhl Jr., 1992). By contrast, confidential informants are citizens who, due to various circumstances and diverse motives, assist law enforcement in an active manner (Fitzgerald, 2007). The essential difference between an informer and an informant is that the former merely transmits information, while the latter seeks it (Bloom, 2002). The CI must be actively involved in seeking out 
damning knowledge on suspects and sometimes developing criminal activity under the direction of the police; thus, he or she may be thought of as a "citizen operative" or an "amateur police agent" (Wisotsky, 1986). The CI must be able to operate, either alone or in conjunction with undercover officers, within natural and fabricated criminal environments for it is the CI's ability to do so that is of real value to the police. Not surprisingly, effective informants are often charged with or convicted of criminal offenses (Blumer, 2009). In fact, a citizen's criminal record and present extent of interaction with active criminals are the two primary variables determining whether police classify an individual as an informer or an informant. Such a classification system is important and functional because it serves to justify officers' assumption of a morally superior and condescending attitude (Bloom, 2002; Schneider, 2008).

The criminal versus non-criminal classification dichotomy seems to be a widespread and longstanding law enforcement standard. The US Bureau of Justice Assistance distinguishes between criminal informants who are co-participants in criminal activity and non-criminal informants, also called sources (Janzen, 1992). Great Britain's National Drug Intelligence Unit differentiates between amateur informers and professional informants, the former being public-spirited individuals not always regarded as welcome and the latter, known as "participating informants", considered the backbone of detective work (Dorn et al., 1992: p. 125). The US Drug Enforcement Administration categorization method specifies Class I informants as those who have criminal records and/or connections and backgrounds and Class II informants who are citizen informers (Boulette \& Andersen, 2015).

Confidential informants enter into exchange relationships whereby their performance is compensated with various tangible and intangible rewards; favorable discretion about pending criminal charges, money, revenge, and, for some, autonomy in unlawful endeavors such as drug use, minor probation violations and even street-level drug dealing (Skolnick, 2016). Remuneration, regardless of type and amount, means that a law enforcement agency is contractually involved, to some degree, with a citizen (Brock-Utne, 2015). Informant work can overlap with other logistical and legal aspects of an investigation, thus requiring a structured relationship for liability as well as procedural reasons. As Manning (2004: p. 141) notes, "the informant must stand in some formal relationship to the police officer and this relationship distinguishes citizens from informants".

Even in areas that promote strong anti-snitching beliefs (e.g., inner city neighborhoods) talking to police is relatively common (Rosenfeld, Jacobs, \& Wright, 2003). Opportunities to inform officials about crime have undoubtedly burgeoned with increased utilization of electronic technologies in investigation and surveillance. Toll-free telephone and text numbers, electronic mail, and even public fax machines are widely available for citizens to turn in drug dealers, wildlife poachers, suspected burglars, and even those who litter often for a reward (Blackmore, 2014). From the law enforcement perspective, informants are 
a necessary, though undesirable element of detective work. Completely jargoned "working" or "taking care of" informants, secret source use involves a triple approach of improvement, administration, and assurance (Billingsley et al., 2001). Until recently, there has been little development (i.e., training) for informants or the officers overseeing them, something of a paradox given that informants are so crucial to undercover success (Dorn et al., 1992). As Manning (2004: p. 141) observes, the situation in the USA is all too similar: "Maintaining their informants, they assume this is the most fruitful way of working, in large part because they have never done anything else, have received little or no formal training". Financing policing through forfeiture oriented undercover operations (Miller \& Selva, 1994) and litigation problems stemming from informant mismanagement (Gardiner, 2002) stimulate the development and implementation of education on informant utilization through positive and negative incentives to protect informant identity respectively (Poltilove, 2009).

In an effort to highlight the regulatory importance of informants as opposed to those generally posed whenever human sources of information become the basis for police activity, let us focus on two groups: 1) their information helps to get those individuals who are faced with the possibility of an arrest on related or unrelated criminal charges, agree to provide information to the police about the criminal activities of others; and 2) those individuals who are perhaps acting at the loose or tight direction of the police, endeavor, notwithstanding their outsider status, to introduce themselves into some ongoing or nascent criminal scheme, usually as a trafficking counterparty or some sort of abettor (i.e., purveyor of needed material) (Goffman, 2013). The second group will not necessarily be motivated by the desire for leniency, cash rewards may do the trick, but it is not likely to include pillars of society. Many informants will sustain structured relationships with one or more police officers or agents. Informants are not a unique feature of narcotics investigations, but they are particularly prevalent in that area (Goddard, 2008).

The criminal background and self-interested motivations of many informants raise tough questions about their reliability and integrity, to some extent, through a patchwork of formal legal doctrines (Hutchins, 2006). When, for example, police draw on information obtained from an informant to support an application for a search or arrest warrant or to justify a warrantless search or arrest, a court will inquire into the informant's reliability (perhaps his "track record" in past cases) and the extent to which he is corroborated (Jacobs, 2003). When an informant helps put in motion the criminal activity for which a defendant is later prosecuted, the defendant may be able to get a court to scrutinize the government's tactics by invoking the court's "supervisory powers" (if the jurisdiction allows) or by raising an entrapment defense before the jury (Jacobs, 2013). The likelihood of obtaining relief under either of these approaches is pretty low, however, because courts are averse to using supervisory powers to regulate police operations, and entrapment defenses open the door to evidence of the de- 
fendant's predisposition to commit the crime. Moreover, what is unlikely to receive any judicial scrutiny at all is the informant's role in target selection-the extent to which enforcement discretion has been effectively outsourced to him. The deference courts give to enforcer discretion which prevents any scrutiny of this de facto power of the informant, with claims of "selective prosecution" doomed to fail (Jacobs, 2007).

The extent that formal doctrine particularly of the sort that can be invoked in the adversary process constrains how the police use informants turns on whether information about police-informant interaction reaches prosecutors (Nugent, Leahy, \& Connors, 2011). With different priorities, interests, and accountabilities, prosecutors will often have different views on the deals that have been cut and the reliability of the information obtained. Prosecutors are also the necessary conduit of information to defense counsel and judges. None of this oversight and transmission can occur, however, when police are not candid with prosecutors about informant activities, and the absence of such candor risks severe miscarriages of justice (Osterburg \& Ward, 2012). Operationally, more significant, sources of regulation are, at least potentially, bureaucratic controls within agencies, and sometimes political oversight. What these are and the degree to which they address informant pathologies vary greatly across jurisdictions (Palmiotto, 2014). The Ghana Attorney General's Guidelines, for example, requires that the Justice Department agencies conduct suitability inquiries before signing up an informant and regular suitability reviews thereafter. Any illegal activity that informants engage in must be authorized and carefully overseen. State and local agencies have their own guidelines, but often look to the policies and standards of the Commission on Accreditation for Law Enforcement Agencies (CALEA) and the International Association of Chiefs of Police (IACP).

\subsection{Theoretical Framework}

As an interpersonal and dynamic process, confidential informing is well suited for interpretation according to a micro interactionist approach. Moral careers (Becker, 2013), deviance constructionism (Adler \& Adler, 2008), social control irony (Deflem, 2002) and neutralization (Benson, 2015) perspectives all situate confidential informing within a general theoretical framework of symbolic interactionism.

The moral careers approach emphasizes distinct stages in labeling processes vital to the development of a deviant identity. Socialization, in which the individual learns and internalizes the norms, customs, and behaviors of "normal" society, sets the stage for stigmatization realization. Realization centers on awareness of consequences associated with, if not inseparable from, stigmatization as other, criminal, or drug nark. This awareness likely conditions role performance as informants weigh options across overlapping mainstream and backstage domains (Goffman, 2014).

Deviance role maintenance, in a sense a layered concern for most informants who are also criminal is informed by neutralization theory (Sykes \& Matza, 2007). 
Accounts featuring an actor and context specific "vocabulary of motive" serve to neutralize wrongful acts and consequences, essentially a means of reconciling deviance as normal (Mills, 2010). Neutralizations and accounts for participation in crime, particularly white-collar crime (Benson, 2015), have been well documented and include denial of responsibility for one's behavior (excuses), condemning the condemners and denial of injury (justifications) (Scott \& Lyman, 2008). In the context of confidential informing, neutralization techniques are likely efforts to shift or transfer guilt for the betrayal inherent to informing to an external source. Collectively, these perspectives provide a conceptual context by which to assess narratives of informing across place and time and situate the practice in the broader realm of undercover enforcement.

\subsection{Conceptual Framework}

Figure 1 below illustrates a conceptual framework which models a uni-directional relationship between the independent variables (i.e. community willingness to fight crime, police strategies to protect informants, reduction in crime and society perception about police) and police informant relationship in the study area (dependent variable). The unilineal relationship is intercepted by some extraneous associations, including protecting informants to reduce crime as more community members will be willing to provide information on criminal activities.

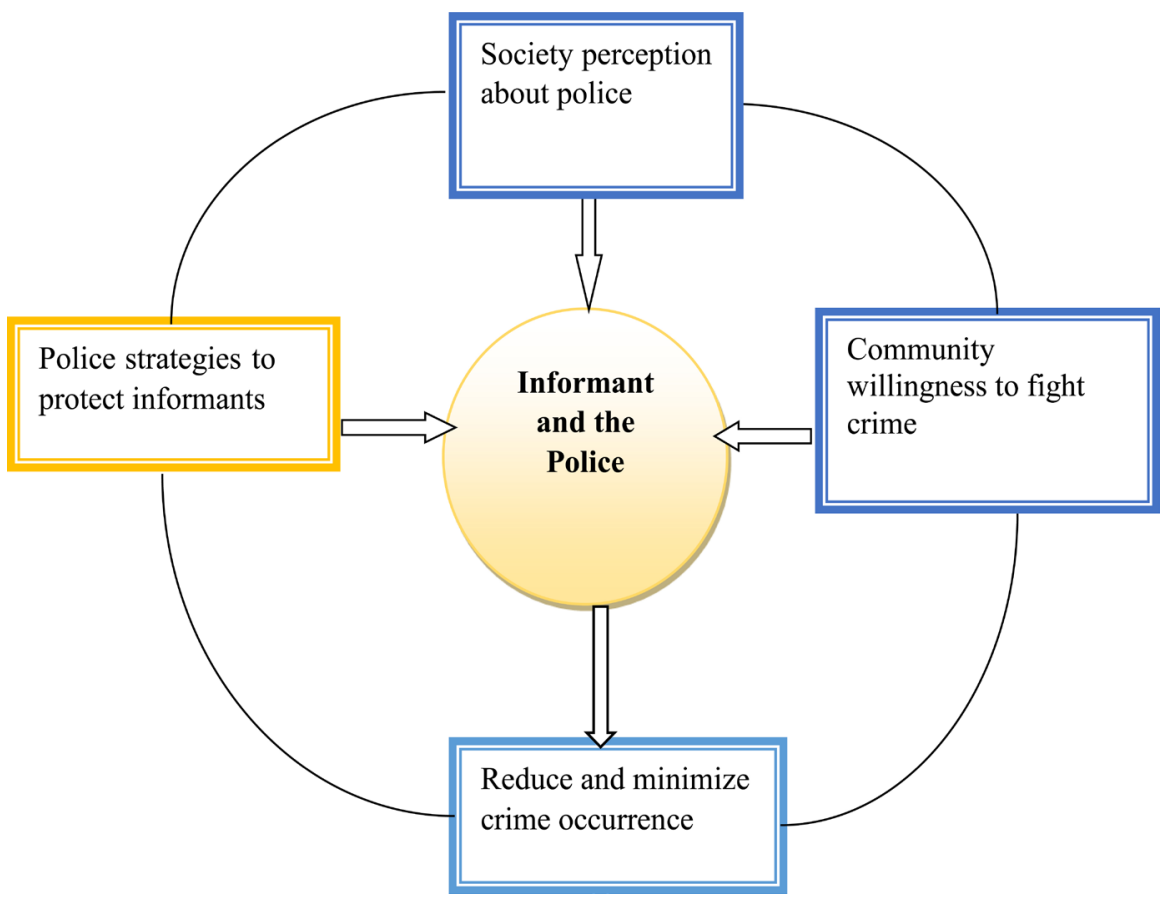

Source: Researchers own construct, 2019.

Figure 1. Conceptual framework on informant and the police.

\section{Methodology}

The study adopted the social survey design to provide intensive empirical data. 
This particular research design was employed because it enabled the researchers to collect quantifiable data on more than one case at a time. This design helped the researchers to assess the useful of informants' information to the police in the area. This study adopted a quantitative approach where data were collected through the use of questionnaires. The quantitative approach was employed for the collection, analysis and presentation of data. Primary and secondary sources of information and ideas were the main sources of data for the study. Probability sampling method was utilized for this study. Specifically, this study adopted the cluster and simple random sampling technique. Cluster and simple random sampling technique were utilized to select the police and community members for this study. Effectively sampling using this technique, study first identified the major communities in the Brong-Ahafo Region of Ghana. The communities were put into 10 clusters using the classifications by the Ghana Electoral Commission (EC). The various electoral communities' classifications by the EC were considered as the clusters. Ten electoral communities were then adopted as the sampling frame where simple random sampling technique was used to select two electoral communities and these were the Tepa and Hwediem communities. After selecting the Tepa and Hwediem communities, the study adopted systematic sampling to select households where the simple random technique was used to select the respondents. A sample size of 400 respondents was selected for this study. The size of the sample was of the fact that it formed a true reflection of the population. Information for the study was collected mainly with the aid of structured interview questionnaire. The choice of structured interview questionnaire enabled respondents who cannot read to also form part of the study, in the sense that the researchers read the questions to the respondents. These questions were also used to meet the objectives of the study. The structured interview questionnaire offered alternatives from which the respondents in the study chose the answers they esteem suitable. The inquiries were utilized to accomplish the targets of the research. The structured interview questionnaire was largely administered by the researchers through face-to-face sessions with respondents. This instrument also helped the researchers reduce biases and errors. The questionnaires also gave greater anonymity to researcher's respondents. The study instrument was tested for reliability and validity before the actual data collection. The researchers adopted a Likert scale range from strongly disagree, disagree, agree and strongly agree to construct the questionnaire. This scale was applied to questions that were asked concerning the study objectives. The structured interview questionnaire was designed on relationship between community members and police in combating crime with focus on the ways they collaborate to fight against crime. This was done using a Likert scale ranging from $1=$ strongly disagree (SD), 2 = disagree (D), $3=$ neutral $(\mathrm{N}), 4=$ agree $(A), 5=$ strongly agree (SA). The respondents were asked to indicate their level of agreement in respect to the set of statements considered as ways in which they collaborate to fight against crime. These ways included: providing the police with information on 
criminal activities, reporting criminals to the police, willingness to help the police in crime investigation and acting as community watchdogs. Using the scale of $1=$ strongly disagree (SD) to $5=$ strongly agree (SA), the respondents' responses were ranked using average $(\bar{x})$ scores to imply that an average $(\bar{x})$ of less than 2.5 means that the respondents disagreed with that particular statement as ways of collaborating to fight against crime, an average $(\bar{x})$ score of 2.5 to 3.4 implied that they were uncertain or neutral with regards to the statement as ways of collaborating to fight against crime and average $(\bar{x})$ score of 3.5 and greater implied that respondents agreed that such statement were seen as ways of collaborating to fight against crime.

Using a Likert scale ranging from $1=$ strongly disagree (SD) to $5=$ strongly agree (SA), informants were asked the effectiveness of their information in fighting crime by the police. The respondents were asked to indicate their level of agreement in respect to the set of statements considered as effectiveness of their information in fighting crime. These effectiveness included: provides accurate information on places crimes are committed, helps police ability to identify suspects, useful in most criminal case investigations, serves as a witness and testimony in the law court, serves as deterrent for criminals, useful in preparing cases for court proceedings and sentencing and helps save innocent victims who may be seen as suspects of any criminal activity. Using the scale of $1=$ strongly disagree (SD) to $5=$ strongly agree (SA), the respondents' responses were ranked using average $(\bar{x})$ scores to imply that an average $(\bar{x})$ of less than 2.5 means that the respondents disagreed with that particular statement as effective in fighting against crime, an average $(\bar{x})$ score of 2.5 to 3.4 implied that they were uncertain or neutral with regards to the statement as effective in fight against crime and average $(\bar{x})$ score of 3.5 and greater implied that respondents agreed that such statement were seen as effective in fighting against crime.

Using a Likert scale ranging from $1=$ strongly disagree (SD) to $5=$ strongly agree (SA), respondents were asked the ways to improve community members and police relationship in protecting informants. The respondents were asked to indicate their level of agreement in respect to the set of statements considered as ways to improve community members and police relationship in protecting informants. These ways included: police giving the right punishment to reported suspects, informants not appearing before suspects they report to the police, names and identifiers of informants should always be kept in secret, rewards given to informant to serve as motivation in order to report criminal activities and police working according to their work ethics in protecting informants. Using the scale of $1=$ strongly disagree (SD) to $5=$ strongly agree (SA), the respondents' responses were ranked using average $(\bar{x})$ scores to imply that an average $(\bar{x})$ of less than 2.5 means that the respondents disagreed with that particular statement as ways to improve community members and police relationship in protecting informants. An average $(\bar{x})$ score of 2.5 to 3.4 implied that they were uncertain or neutral with regards to the statement as ways to improve 
community members and police relationship in protecting informants and average $(\bar{x})$ score of 3.5 and greater implied that respondents agreed that such statement were seen as ways to improve community members and police relationship in protecting informants.

Data collected with the use of questionnaires were coded and analyzed with the aid of SPSS (Statistical Package for Social Sciences) software. SPSS helped to generate table and charts for the analysis. The data was analyzed using both uni-variate and bivariate analysis. Descriptive statistical tools such as means and standard deviation were also used to analyze the data. The primary area of ethical issues that the researchers considered incorporated the informed consent, invasion of privacy, anonymity and confidentiality. High level of confidentiality and anonymity was respected. This study was devoid of the names of the prospective respondents. Informed consent was sought through verbal approval. Ethical approval was also sought from the Department of Sociology and Social Work, of the Kwame Nkrumah University of Science and Technology before commencement to the field. However, ethical approval was also sought from the chiefs of the various communities and also from the Head of Authorities of the police station in the communities.

The constraint the study encountered included financial and time constraint. Some police officers did not have enough time to interact with the researcher due to the nature of their work. Equally, there were no enough time for the researchers to involve more police officers and stations rather than selecting only one police station in the study and that made the researchers data limited in scope. At the initial stage some respondents were unwillingly to take part in the study for fear of community perception about informants. For this reason, the researchers assured the respondents of the confidentiality of information and also had to motivate some respondents by giving them money to encourage others to participate in this study.

\section{Results of the Study}

This study seeks to examine the relationship between the community members and the police in providing information for the police to combat crime, determine the effectiveness of informants' information in fighting crime and identify possible measures that could improve the relationship between the community and police in protecting informants.

\subsection{Community Members and Police Relations in Combating Crime}

This study sought to examine the relationship between community members and the police in providing information to combat crime. This study then sought to inquire from respondents if they have ever reported a criminal case and the findings of this study revealed that $67 \%$ of the respondents indicated that they have never reported any criminal case whiles $33 \%$ of the respondents indicated 
that they have reported a criminal case. The results showed that majority of the respondents have never reported any criminal case to the police. This could be to the fact that a good number of the respondents do not have good relationship with police with regards to protection of privacy of informants. This concur the point made by Benson (2015) asserting that $20 \%$ - 36\% of community members do not feel secured in providing information about criminal activities to the police. Out of the $33 \%$ who indicated that they have reported a criminal case, the study again sought to find out which categories of respondents report most criminal cases to the police. It was revealed that $57 \%$ were victims, $24 \%$ were eye witness to the crime and $19 \%$ were informants. The results of the study implied that informants were relatively lower. It also implied that most communities do not provide information to the police in fighting crime unless they were victims. The results of the study implied that victims were most likely the community members to report cases to the police. It was also found that few eye witnesses also reported cases to the police. The results of the study means that the police have more work to do in order to gain more information from informants and eye witnesses of crime since such people were few. In the view of Bergstrom (2015), victims of crime are mostly the majority in terms of crime reported to the police. The study then again sought to find out the importance of respondents' report of criminal cases to the police in fighting crime. Findings of the study established that $37 \%$ of the respondents who reported criminal cases to the police indicated that their act was very important in fighting crime, $42 \%$ of argued that their act was important in fighting crime and $21 \%$ felt that the information they provided to the police on criminal activities was not important in fighting crime. The results of the study implied that majority of the respondents were aware of the importance of reporting criminal activities to the police. It also implied that most information provided to the police on criminals activities were useful to the police in fighting crime. The study again sought to find out the use of the information given by respondents to the police. It was revealed that most respondents who reported criminal cases to the police, $46 \%$ of such reports led to the arrest and sentence of perpetrators, $31 \%$ led to the arrest of suspects but did not result in the sentencing of perpetrators and 23\% felt that their act led the police to strengthen security measures in the areas to prevent future criminal activities. The results of the study implied that reporting criminal cases to the police by respondents had positive impact in fighting crime as most respondents argued that reporting crime led to arrest and sentence of suspects. In the view of Blackmore (2014) when criminal activities are reported to the police by community members, the police are able to effectively fight crime. Wisotsky (1986) noted that reporting crime to the police help in arresting and punishing perpetrators. In the quest to find out the various ways respondents collaborate with the police in fighting crime, it was found that report of criminals to the police was a way to fight crime and this recorded a mean score of 4.74 , a standard deviation of 1.415. This was closely followed by respondents providing the police 
with information on crime activities which recorded a mean score of 4.52 and a standard deviation of 1.218. The study further found that most of the respondents were not willing to help the police in crime investigations; having a mean score of 3.43 and a standard deviation of 1.016 and lastly acting as community watchdog was seen as another way respondents collaborate with the police in fighting crime with a mean score 3.36 and a standard deviation of 1.314 . The results of the study implied that the community members were collaborating well with the police in fighting crime through the provision of information to the police on criminal activities and reporting criminals to the police (Table 1).

\subsection{Effectiveness of Informants' Information in Fighting Crime}

This study sought to examine the effectiveness of informants' information in fighting crime. The findings of the study revealed that majority of the respondents agreed that informants provide accurate information on places crimes are committed and this recorded a mean score of 4.78 and a standard deviation of 1.25 which implied that majority of the respondents strongly agreed that informants help the police in fighting crime by providing the police with accurate places in which crime occur. The study also found that most of the respondents agreed that informants help the police to identify suspects which having a mean score of 4.53 and a standard deviation of 0.96 . The third factor most respondents agreed to was that the police used informants' information is useful in most criminal cases investigation which recorded a mean score of 4.37 and a standard deviation of 0.93 . The study further found that the police use informants' information in preparing cases for court process and sentencing with a mean score of 4.17 and a standard deviation of 0.92 . There were some factors respondents did not consider as effective of informants' information. The study found that most of the respondents were uncertain as to whether the willingness of people to serve as informants is a deterrent for criminals or not which recorded a mean score of 3.42 and a standard deviation of 1.04. Equally, respondents were uncertain as to whether informants help to save innocent victims who may be considered suspect of criminal activities which was seen as the sixth effectiveness with a mean score of 3.30 and a standard deviation of 1.00. Lastly, according to the respondents, most informants may not like to act or serve as witness and testimony in law court as that may lead to revealing their identify. The study found

Table 1 . Ways community members collaborate with the police in fighting crime.

\begin{tabular}{lccc}
\hline Community collaboration with police & Mean & St. Dev. & Rank \\
\hline Providing the police with information on criminal activities & 4.52 & 1.218 & $2^{\text {nd }}$ \\
Report of criminals to the police & 4.74 & 1.415 & $1^{\text {st }}$ \\
Willingness to help the police in crime investigations & 3.43 & 1.016 & $3^{\text {rd }}$ \\
Act as community watchdog & 3.36 & 1.314 & $4^{\text {th }}$ \\
\hline
\end{tabular}

Source: Field Survey Results, 2019. 
that most of the respondents strongly disagreed that informants serve as witness and testimony in the law court having recorded a mean score of 1.05 and a standard deviation of 1.37. The findings of the study confirmed previous studies on effectiveness of informants' information in fighting crime. It is argued that a number of investigations by the police would not go anywhere; especially without informants (McCall, 2008). In addition, the risk that partners may inform the police will destabilize tricks and along these lines lessen the long haul accomplishment of criminal investigation (Miller, 2011). Then again, on the grounds that informants can substitute for more concentrated investigative work, police officers might be enticed to "over purchase" informant information and disregard more criminal movement by informants than would normally be appropriate to ensure arrest of suspects. What is more important about suspects is that the apparent feeling of exemption with respect to informants can just espouse crime (Miller \& Selva, 1994). Obviously informants themselves do not mislead police (Mills, 2010). The person who faces arraignment since he declined to work with the police will at any rate have some adjudicative shields, including a legal counselor. The person who consents to give information will habitually not have had the advantage of insight and will, not at all like the honest bystander, end up at risk of ill-conceived and unconstrained police misuse (Mount Jr., 2011) (Table 2).

\subsection{Measures to Improve Community Members and Police Relationship in Protecting Informants}

This study sought to examine the measures that can help improve community members and police relationship in protecting informants. Findings of the study showed that majority of the respondents with mean score of 4.78 and a standard deviation of 1.33 strongly agreed that informants should be protected by the police by ensuring that informants' identities are not revealed to suspects. The study found that respondents agreed that if informants are not be made to appear before suspects they report to the police, their identities will be well protected and that

Table 2. Effectiveness of informants' information in fighting crime.

\begin{tabular}{lccc}
\hline Effectiveness of informants' information & Mean Std. Dev. Rank \\
\hline Informant provide accurate information on places crimes are committed & 4.78 & 1.25 & $1^{\text {st }}$ \\
Informant help the police to identify suspects & 4.53 & 0.96 & $2^{\text {nd }}$ \\
Informant information is useful in most criminal cases investigation & 4.37 & 0.93 & $3^{\text {rd }}$ \\
Informant information serves as witness and testimony in the law court & 1.05 & 1.37 & $7^{\text {th }}$ \\
The willingness of people to serve as informants is a deterrent for criminals & 3.42 & 1.04 & $5^{\text {th }}$ \\
$\begin{array}{l}\text { The police use informant's information in preparing cases for court process } \\
\text { and sentencing }\end{array}$ & 4.17 & 0.92 & $4^{\text {th }}$ \\
$\begin{array}{l}\text { Informant help to save innocent victims who may be considered suspect of } \\
\text { criminal activities }\end{array}$ & 3.30 & 1.00 & $6^{\text {th }}$
\end{tabular}

Source: Field Survey Results, 2019. 
will help promote community-police relationship in protecting informants. However, respondents indicated that through the protection of their names and identifiers by the police, it would help improve their relationship which had a mean score of 4.66 and a standard deviation of 1.53. This implied that keeping informants' name and identifiers as secret was central in promoting community police relationship on fighting crime and protecting informants. Equally, respondents agreed that individual who provide the police with useful information on criminal activities should be rewarded and this recorded a mean score of 4.48 and a standard deviation of 1.04 which implied that when informants are rewarded, they will be willing to provide the police with information on criminal activities. It was found that majority of the respondents agreed that the police should work according to their work ethics in protecting informants having recorded a mean score of 4.27 and a standard deviation of 1.21. It was also revealed that suspects reported by informants should be given the right punishment by the police who recorded a mean score of 4.14 and a standard deviation of 1.17. The results implied that if the police work according to their ethics and should punish suspects when informants report criminals to the police, it will serve as ways to promote community-police relationship in fighting crime and protecting informants. The results of the study confirmed the previous researchers made by Janzen (1992); Bloom (2002); Miller \& Selva (1994) asserting that informants' administration best practices to protect them are, to some degree, expected to amplify resource seizure, as confirmed by a US Division of Justice support unit. Informants condition association elements and ethically unrivaled position in providing information to the police and must be protected for giving information to help fight crime (Table 3).

\section{Conclusion}

The findings of the study have adequately satisfied its objectives. In the first place, the study concluded that informants were relatively fewer in the community.

Table 3. Measures to improve community members and police relationship in protecting informants.

\begin{tabular}{|c|c|c|c|}
\hline $\begin{array}{l}\text { Improving community police relationship toward protection of } \\
\text { informants }\end{array}$ & Mean & Std Dev. & Ranks \\
\hline $\begin{array}{l}\text { Suspects reported by informant should be given the right punishment by } \\
\text { the police }\end{array}$ & 4.14 & 1.17 & $5^{\text {th }}$ \\
\hline $\begin{array}{l}\text { Informants should not be made to appear before suspects they report to } \\
\text { the police }\end{array}$ & 4.78 & 1.33 & $1^{\text {st }}$ \\
\hline The names and identifiers of informants should always be kept as secret & 4.66 & 1.53 & $2^{\text {nd }}$ \\
\hline $\begin{array}{l}\text { Individual who provide the police with useful information on criminal } \\
\text { activities should be rewarded }\end{array}$ & 4.48 & 1.04 & $3^{\text {rd }}$ \\
\hline The police should work according to work ethics in protecting informants & 4.27 & 1.21 & $4^{\text {th }}$ \\
\hline
\end{tabular}

Source: Field Survey Result, 2018. 
Most people who report cases to the police were victims. The study concluded that respondents who reported criminal cases to the police indicated that their act was very important in fighting crime. The study further concluded that for most respondents who reported crime to the police, the majority of such reports led to the arrest and sentence of perpetrators. The study concluded that the police rely on accurate informants' information in investigating and arresting criminals. The study further concluded that the police use informant's information in preparing cases for court process and sentencing. The study concluded that most of the respondents strongly disagreed that informants serve as witness and testimony in the law court. It was concluded that a good relationship between the community members and the police was needed if the police were to protect informants. The respondents stated that informants should not be made to appear before suspects they report to the police. The results of the study showed that the majority of the respondents strongly agreed that informants should be protected by the police by ensuring that informants' identities were concealed.

\section{Recommendations}

The following recommendations were offered based on the research results.

The researchers recommended that since effective communication is fundamental to positive police-community relationships, the Government and Ghana Police Service (GPS) should seek to provide it officers with an understanding of language diversity.

The researchers then again recommended that officers of the GPS should be provided with an in-service training by the Government and GPS to improve community policing and trust building. This will help reinforce trust with the community members (informants) to report suspects.

The researchers recommended that the Government should integrate community policing activities into performance evaluation systems.

The researchers then again recommended that strict punishment should be given to suspects reported by the informants by the Government and GPS.

The researchers recommended that an outreach or public education to be conducted to educate informants on the relevance of community-police relationships in order to curb the issues of crime.

\section{Conflicts of Interest}

The authors declare no conflicts of interest regarding the publication of this paper.

\section{References}

Adkins, T. E. (2007). Informant Polygraph Testing. Polygraph, 16, 106-115.

Adler, P. A., \& Adler, P. (2008). Constructions of Deviance (6th ed.). Belmont, CA: Wadsworth. 
Becker, H. (2009). Outsiders: Studies in the Sociology of Deviance. New York: Free Press.

Becker, H. (2013). Becoming a Marihuana User. American Journal of Sociology, 59, 235-242. https://doi.org/10.1086/221326

Benson, M. L. (2015). Denying the Guilty Mind: Accounting for Involvement in a White Collar Crime. Criminology, 23, 589-599.

Bergstrom, K. (2015). Police Experimentation with Civilian Subjects: Formalizing the Informal. In Police Leadership in America: Crisis and Opportunity. New York: Praeger.

Billingsley, R., Nemitz, T., \& Bean, P. (Eds.) (2001). Informers: Policing, Policy, Practice. Cullompton, UK: Willan.

Blackmore, J. (2014). The Relationship between Self-Reported Delinquency and Official Convictions amongst Adolescent Boys. British Journal of Criminology, 14, 172-176. https://doi.org/10.1093/oxfordjournals.bjc.a046535

Bloom, R. (2002). Ratting: The Use and Abuse of Informants in the American Justice System. Westport, CT: Praeger.

Blumer, H. (2009). Symbolic Interactionism: Perspective and Method. Englewood Cliffs, NJ: Prentice-Hall.

Boulette, T. R., \& Andersen, S. M. (2015). Mind Control and the Battering of Women. Community Mental Health Journal, 21, 109-118. https://doi.org/10.1007/BF00754370

Brock-Utne, B. (2015). Educating for Peace. New York: Pergamon Press.

Brown, E. (2007). Snitch: Informants, Cooperators, and the Corruption of Justice. New York: Public Affairs.

Caldero, M. A., \& Crank, J. P. (2010). Police Ethics: The Corruption of Noble Cause (2nd ed.). Cincinnati, $\mathrm{OH}$ : Anderson Publishing.

Chatterton, M. R. (2009). Managing Paperwork. In M. Weatheritt (Ed.), Police Research: Some Future Prospects (pp. 107-136). Aldershot, England: Avebury.

Clark, J., \& Tiff, L. (2016). Polygraph and Interview Validation of Self-Reported Deviant Behavior. American Sociological Review, 31, 516-523. https://doi.org/10.2307/2090775

Deflem, M. (2002). Policing World Society. Oxford: Oxford University Press.

Donnelly, R. C. (2011). Judicial Control of Informants, Spies, Stool Pigeons, and Agent Provocateurs. The Yale Law Journal, 60, 1091-1131. https://doi.org/10.2307/793692

Dorn, N., Murji, K., \& South, N. (1992). Traffickers: Drug Markets and Law Enforcement. London: Routledge.

Fitzgerald, D. (2007). Informants and Undercover Investigations: A Practical Guide to Law, Policy and Procedure. Boca Raton, FL: CRC Press. https://doi.org/10.1201/9780849304132

Gardiner, P. A. (2002). Criminal Investigation's Use of Confidential Funds for Undercover Operations Is Appropriate; However, Certain Aspects of Undercover Operations Need Improvement. Washington DC: U.S. Department of Justice.

Geberth, V. J. (2009). Confidential Informant. Law and Order, 27, 38-41.

Goddard, D. (2008). Undercover: The Secret Lives of a Federal Agent. New York: Times Books.

Goffman, E. (2013). Stigma. Englewood Heights, NJ: Prentice-Hall.

Goffman, E. (2014). Frame Analysis. New York: Harper \& Row.

Harney, M. L., \& Cross, J. C. (2008). The Informer in Law Enforcement (2nd ed.). Springfield, IL: Charles C. Thomas. 
Hartley, R. D., Maddan, S., \& Spohn, C. (2007). Prosecutorial Discretion: An Examination of Substantial Assistance Departures in Federal Crack-Cocaine and Powder-Cocaine Cases. Justice Quarterly, 24, 382-407. https://doi.org/10.1080/07418820701485379

Hutchins, M. (2006). Informants: Protecting Their Identity. Point of View: Journal of the Alameda District Attorney's Office.

Jacobs, B. A. (2003). Undercover Deception Clues: A Case of Restrictive Deterrence. Criminology, 31, 281-299. https://doi.org/10.1111/j.1745-9125.1993.tb01131.x

Jacobs, B. A. (2007). Contingent Ties: Undercover Drug Officers' Use of Informants. British Journal of Sociology, 48, 35-53. https://doi.org/10.2307/591909

Jacobs, B. A. (2013). Getting Narced: Neutralization of Undercover Identity Discreditation. Deviant Behavior, 14, 187-208. https://doi.org/10.1080/01639625.1993.9967939

Janzen, S. (1992). Informants and Undercover Investigations. Washington DC: U.S. Bureau of Justice Assistance.

Lum, C., \& Nagin, D. S. (2017). Reinventing American Policing. Crime and Justice, 46, 339-393. https://doi.org/10.1086/688462

Manning, P. K. (2004). The Narc's Game: Organizational and Informational Limits on Drug Law Enforcement (2nd ed.). Prospect Heights, IL: Waveland Press.

McCall, G. (2008). Observing the Law. New York: Free Press.

Miller, J. M. (2011). Becoming an Informant. Justice Quarterly, 28, 203-220. https://doi.org/10.1080/07418825.2010.506881

Miller, J. M., \& Selva, L. H. (1994). Drug Enforcement's Double-Edged Sword: An Assessment of Asset Forfeiture Programs. Justice Quarterly, 11, 313-335. https://doi.org/10.1080/07418829400092271

Mills, C. W. (2010). Situated Actions and Vocabularies of Motive. American Sociological Review, 5, 904-913. https://doi.org/10.2307/2084524

Mount Jr., H. A. (2011). Criminal Informants: An Administrator's Dream or Nightmare. Prosecutor, 24, 23-26.

Nugent, H., Leahy, F. J., \& Connors, E. F. (2011). Managing Confidential Informants. Washington DC: U.S. Department of Justice.

Osterburg, J. W., \& Ward, R. H. (2012). Criminal Investigation: A Method for Reconstructing the Past. Cincinnati, OH: Anderson. https://doi.org/10.4324/9781315721866

Palmiotto, M. (2014). Confidential Informant: Management and Control. Cincinnati, $\mathrm{OH}$ : Anderson.

Pfuhl Jr., E. H. (1992). The Legitimation of Snitching. Justice Quarterly, 9, 505-528. https://doi.org/10.1080/07418829200091501

Poltilove, J. (2009). Rachel's Law on Confidential Informants Takes Effect Wednesday. The Tampa Tribune.

Rosenfeld, R., Jacobs, B., \& Wright, R. (2003). Snitching and the Code of the Street. British Journal of Criminology, 43, 291-309. https://doi.org/10.1093/bjc/43.2.291

Schneider, S. K. (2008). Art of Darkness: Street Acting by Undercover Operators, Con Men, and Others. Chicago, IL: Cuneiform Books.

Schreiber, A. J. (2001). Dealing with the Devil: An Examination of the FBI's Troubled Relationship with its Confidential Informants. Columbia Journal of Law and Social Problems, 34, 301-368.

Schulhofer, S. J. (2013). Rethinking Mandatory Minimums. Wake Forest Law Review, 28, 211-12. 
Scott, M. B., \& Lyman, S. M. (2008). Accounts. American Sociological Review, 33, 46-62. https://doi.org/10.2307/2092239

Skolnick, J. H. (2016). Justice without Trial: Law Enforcement in Democratic Society. New York: John Wiley \& Sons.

Sykes, G. M., \& Matza, D. (2007). Techniques of Neutralization: A Theory of Delinquency. American Sociological Review, 22, 664-670. https://doi.org/10.2307/2089195

Weiss, M. W. (2016). Traffic Enforcement, Policing, and Crime Rates. Walden Dissertations and Doctoral Studies. Walden University.

Wisotsky, S. (1986). Breaking the Impasse in the War on Drugs. Westport, CN: Greenwood Press. 